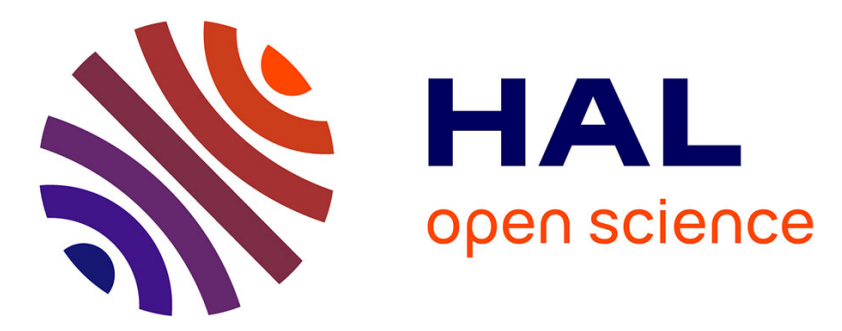

\title{
ELECTROREFLECTANCE OF THIN ZINC SULFIDE FILMS GROWN BY ATOMIC LAYER EPITAXY AND ELECTRON BEAM EVAPORATION TECHNIQUES
}

J. Lahtinen, T. Tuomi

\section{- To cite this version:}

J. Lahtinen, T. Tuomi. ELECTROREFLECTANCE OF THIN ZINC SULFIDE FILMS GROWN BY ATOMIC LAYER EPITAXY AND ELECTRON BEAM EVAPORATION TECHNIQUES. Journal de Physique Colloques, 1983, 44 (C10), pp.C10-239-C10-242. 10.1051/jphyscol:19831050 . jpa00223507

\section{HAL Id: jpa-00223507 https://hal.science/jpa-00223507}

Submitted on 1 Jan 1983

HAL is a multi-disciplinary open access archive for the deposit and dissemination of scientific research documents, whether they are published or not. The documents may come from teaching and research institutions in France or abroad, or from public or private research centers.
L'archive ouverte pluridisciplinaire HAL, est destinée au dépôt et à la diffusion de documents scientifiques de niveau recherche, publiés ou non, émanant des établissements d'enseignement et de recherche français ou étrangers, des laboratoires publics ou privés. 


\title{
ELECTROREFLECTANCE OF THIN ZINC SULFIDE FILMS GROWN BY ATOMIC LAYER EPITAXY AND ELECTRON BEAM EVAPORATION TECHNIQUES
}

\author{
J.A. Lahtinen and T. Tuomi
}

Laboratory of Physics, Helsinki University of Technology, SE-02150 Espoo 15, Finland

\begin{abstract}
Résumé - Nous avons mesuré les spectres d'électroréflectance de couches minces polycristallines de $\mathrm{ZnS}$ :Mn obtenues par "atomic layer epitaxy" et par évaporation. De l'énergie f; de la transition électronique directe observée à 3,74 et 3,705 ev respectivement, on déduit que les couches minces de ZnS formées par épitaxie en couche atomique sont essentiellement de structure hexagonale, alors que la structure đes couches déposées par évaporation à l'aide d'un canon à électrons est proche de celle des polytypes $4 \mathrm{H}$ ou $6 \mathrm{H}$.
\end{abstract}

\begin{abstract}
We have measured electroreflectance spectra of polycrystalline Zns:Mn thin films grown using atomic layer epitaxy and electron beam evaporation techniques for electroluminescent devices. From the $E_{0}$ direct electron transition observed at $3.74 \mathrm{eV}$ and $3.705 \mathrm{eV}$ it is concluded that the $\mathrm{ans}$ thin films grown by atomic layer epitaxy are predominantly hexagonal whereas the crystal structure of the films grown by electron beam evaporation is close to polytype $4 \mathrm{H}$ or $6 \mathrm{H}$.
\end{abstract}

Because of their derivative nature, the modulation techniques have become an important tool in studying optical structure of solids/1-4/. In this investigation we have exploited electric field modulation (electroreflectance, ER) to obtain information about the absorption edge of zinc sulfide.

Theoretical analysis of the ER spectra starting from the coupling of the field to the electrons is very complicated (e.g. because of the insufficient knowledge of the effective field /2/), and therefore it has become customary to determine the critical point parameters (energy gap $\mathrm{E}_{\mathrm{g}}$, lifetime broadening $\Gamma$ etc.) by fitting the measured spectrum to the resonance lineshapes of the form /5-6/:

$$
\frac{\Delta R}{R}=\operatorname{Re}\left\{C e^{i \theta}\left(E-E_{g}+i \Gamma\right)^{-n}\right\} \text {. }
$$

Zinc sulfide crystallizes in cubic, hexagonal and several polytype structures, each of them having the first electron transition $E_{O}$ at different photon energies. By determining $E_{0}$ from the $\mathrm{ER}$ spectrum it is possible to assess the crystal structure of the zinc sulfide sample.

\section{Experimental}

The ZnS samples were grown using two different methods. The ZnS:Mn film in the layer structure of the EL device of Fig. 1 (a) was grown by atomic layer epitaxy (ALE) at about $500^{\circ} \mathrm{C} / 7 /$. The $\mathrm{ZnS}: \mathrm{Mn}$ thin film shown in the EL device of Fig. 1 (b) was deposited by electron beam evaporation (EBE) on a substrate at a temperature of about $180^{\circ} \mathrm{C} / 8 /$. The Mn concentration of the samples was about 0.58 by weight. 


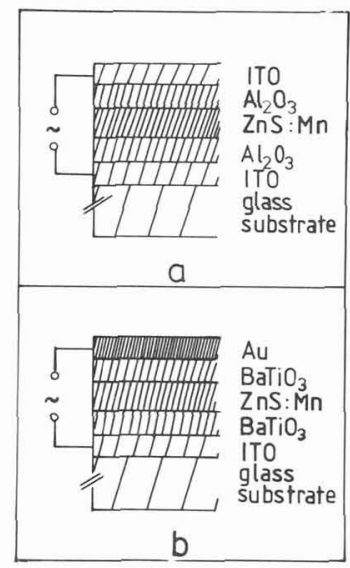

Pig. 1. Samples used in the ER measurements: (a) grown using ALE (b) grown using EBE.

ER spectra were measured with a standard equipment / $1 /$ at room temperature. The light source consisted of a xenon lamp and a Jobin-Yvon HRDl double monochromator with a $2.6 \mathrm{~nm}$ bandwidth. The signal from the photomultiplier was analyzed by a PAR 124A lock-in amplifier and the spectra were registered with an Apple II microcomputer. The output signal level of the photomultiplier was held constant (IV) by automatic adjustment of the bias voltage. The modulating voltage was $5 \mathrm{~V}$ and its frequency was $289 \mathrm{~Hz}$. The average field strength in the $\mathrm{znS}: \mathrm{Mn}$ layer was about $4 \times 10^{6} \mathrm{Vm}^{-1}$ in the ALE films and $1.5 \times 10^{6} \mathrm{Vm}^{-1}$ to $2.0 \times 10^{6} \mathrm{Vm}^{-1}$ in the EBE films. The modulating voltage was well below the threshold voltage (about 130v) of electroluminescence.

\section{Results and discussion}

The low field electroreflectance spectra of polycrystalline $\mathrm{ZnS}$ :Mn films in the energy range from $3.5 \mathrm{eV}$ to $4.0 \mathrm{eV}$ are shown in Fig. 2. The energy $E_{O}$ and the broadening parameter $T$ were determined from the spectra by the three-point method $/ 5 /$, in which the baseline and two dominant peaks are used to fit the spectrum to eq. (1). The values of $E_{O}$ and $\Gamma$ are $3.74 \mathrm{eV}$ and $58 \mathrm{meV}$ in the spectrum a of Fig. 2 and $3.705 \mathrm{eV}$ and $60 \mathrm{meV}$ in the spectrum $\mathrm{b}$. The $E_{\mathrm{O}}$ values measured from several samples do not differ from these (average) values by more than $\pm 10 \mathrm{meV}$ in the ALE films and $\pm 5 \mathrm{meV}$ in the EBE films.

The calculated change of the first direct gap $\Delta \mathrm{E}_{\mathrm{O}}$ caused by the different thermal expansion coefficients of the dielectric layer and the Zns layer is $-2 \mathrm{meV}$ in ALE samples (grown at $500^{\circ} \mathrm{C}$ ). This value is so 


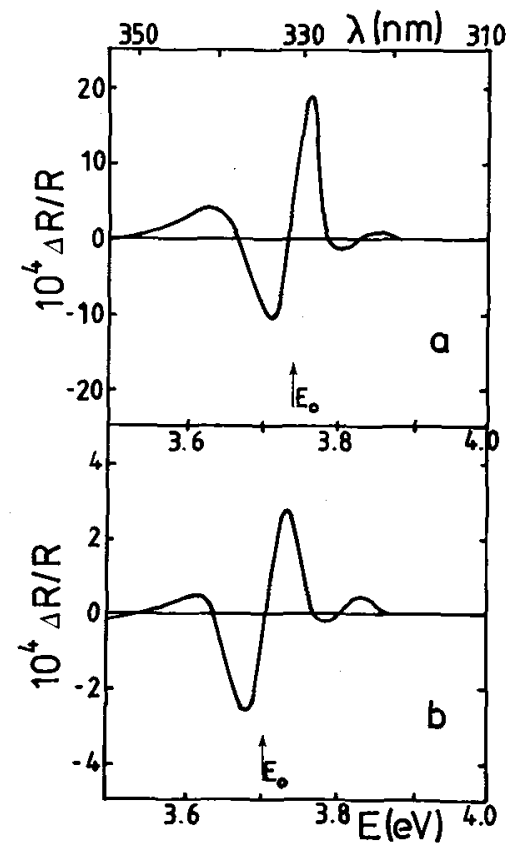

Fig. 2. Electroreflectance spectrum of polycrystalline $\mathrm{znS}: \mathrm{Mn}$ thin films grown using (a) atomic layer epitaxy and (b) electron beam evaporation.

small that no correction need be made to the measured $E_{O}$ due to macrostrain.

From earlier reflectivity measurements /9-12/, it has been suggested that wurtzite type zns crystals can be distinguished from $z$ inc blende type crystals with the aid of the location of the $E_{0}$ transition peak. Variation of the gap $\mathrm{E}_{\mathrm{O}}$ measured with light polarized perpendicularly to the hexagonal C-axis $(\mathrm{E} \perp \mathrm{C})$ with structure of $\mathrm{znS}$ is presented in Fig. 3. The $E_{0}$ values of the two types of thin film studied in the present work are marked by arrows. On the ground of x-ray diffraction studies $/ 14 /$ we had in the ER measurements on the ALE samples the electric field of light nearly perpendicular to the c-axis of the hexagonal $\mathrm{znS}(\mathrm{E} \perp \mathrm{C})$.

From Fig. 3 it can be concluded, that the crystal structure of the polycrystalline $\mathrm{zns}$ thin films grown by the ALE method at about $500^{\circ} \mathrm{C}$ is mainly hexagonal, whereas the structure of the zinc sulfide films deposited by EBE is close to polytype $4 \mathrm{H}$ or $6 \mathrm{H}$. The results of the present work are in good qualitative agreement with the electroluminescence, photoluminescence and $x$-ray diffraction measurements /14-17/. 


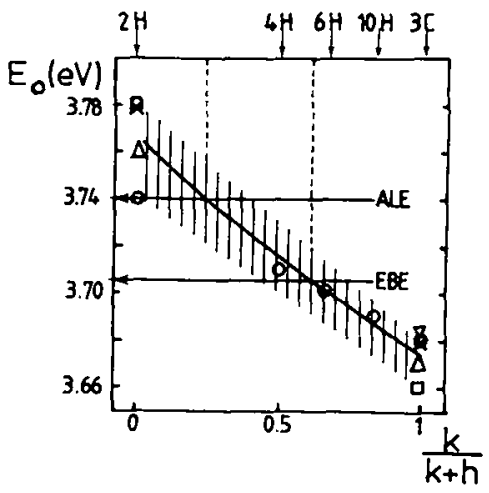

Fig. 3. Variation of the first direct energy gap $E_{O}$ measured with light polarized perpendicularly to the hexagonal c-axis with structure of $\mathrm{znS} . \mathrm{k} /(\mathrm{k}+\mathrm{h})$ is the proportion of cubic packing. $\mathrm{a}, 0, \Delta, \mathrm{x}$ and $\mathrm{V}$ are taken from the room temperature reflectivity /9-12/ and wavelength modulated reflectivity /13/ spectra of $\mathrm{ZnS}$ single crystals, respectively. The results of the present work are marked by arrows.

\section{References}

1/ CARDONA, M. , Modulation Spectroscopy, New York and London, Academic Press, (1969).

/2/ SERAPHIN, B. O., Optical properties of Solids, ed. Abeles, NorthHolland, Amsterdam, (1972) 163.

/3/ HAMAKAWA, Y. and T. NISHINO, Optical Properties of Solids, ed. Seraphin, North-Holland, Amsterdam, (1976) 255.

14/ ASPNES, D. E., Handbook on Semiconductors, Vol. 2: Optical Properties of Solids, ed. Balkanski, North-Holland, Amsterdam, (I980) 109 .

/5/ ASPNES, D. E. and J. E. ROWE, Phys. Rev. Lett. 27 (1971) 188.

/6/ ASPNES, D. E. Surface Science 37 (1973) 418.

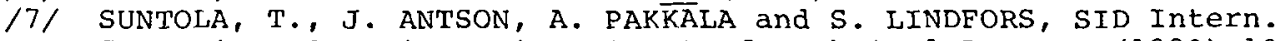
Symposium, San Diego, in: Digest of Technical Papers, (1980) 108.

/8/ VENGHAUS, H., D. THEIS, H. OPPOLZER and S. SCHILD, J. Appl. Phys. 53, (1982) 4146 .

19/ CARDONA, M. and G. HARBEKE, Phys. Rev. 137 (1965) 1467.

110/ BAARS, J. W., Proc of the Intern. Conf. on II-VI Semiconducting Compounds, Providence, (1967) 631.

/11/ DREWS, R. E., E. A. DAVIS and A. G. LEIGA, Phys. Rev. Lett. 18 (1967) 1194 .

/12/ EBINA, A., E. FUKUnAGA and T. TAKAHASHI, Phys. Rev. B 12 (1975) 687 .

/13/ THEIS, D., phys. stat. sol. (b) 79 (1977) 125.

/14/ TANNINEN, V. P., M. OIKKONEN and T. O. TUOMI, phYs. stat. sol. (a) 67 (1981) 573 .

115/ TANNINEN, V. P., T. TUOMI, M. C. TYPPI, R. O. TÖRNQVIST, T. SUNTOLA, J. ANTSON, A. PAKKALA, and S. LINDFORS, PrOc. of the Eight Intern. Vacuum Congress, Cannes, Vol 1, Thin Films, (1980) 401.

$116 /$ BUSSE, W. , H.-E. GUMLICH, R. O. TÖRNQVIST and V. P. TANNINEN, phys. stat. sol. (a) 76 (1983) 553.

/17/ TANNINEN, V.-P., M. OIKKONEN and T. O. TUOMI, Comparative Studies of Crystal Phase, Crystallite Size and Microstrain in the Electroluminescent $\mathrm{ZnS}$ :Mn Films Grown by Atomic Layer Epitaxy and Electron Beam Evaporation, submitted to Thin Solid Films, (1983). 